\title{
Hubungan Spektrum Klinis Infeksi Dengue dengan Kadar Seng dan Feritin Serum
}

\author{
Vindy Ruslianti, Alex Chairulfatah, Dedi Rachmadi \\ Departemen Ilmu Kesehatan Anak Fakultas Kedokteran Universitas Padjadjaran/Rumah Sakit Dr. Hasan \\ Sadikin, Bandung
}

\begin{abstract}
Latar belakang. Sindrom syok dengue (SSD) merupakan masalah kesehatan dengan morbiditas dan mortalitas tinggi. Infeksi dengue dapat menyebabkan badai sitokin dan produksi berlebih MMP-2 dan MMP-9, yaitu suatu enzim yang tergantung seng. Sitokin ini akan menyebabkan peningkatan feritin sebagai reaktan fase akut, sedangkan produksi berlebih MMP-2 dan MMP-9 menjadi salah satu penyebab kebocoran plasma. Tujuan. Menganalisis hubungan spektrum klinis infeksi dengue dengan kadar seng dan feritin serum pada anak.

Metode. Penelitian cross-sectional dilaksanakan dari Januari 2012 sampai Mei 2012 melibatkan 39 anak lakilaki dan 42 anak perempuan. Dilakukan pemeriksaan kadar seng serum dengan metode atomic absorption spectroscopy (AAS) dan feritin serum dengan metode electrochemiluminescense immunoasssay (ECLIA). Uji statistik dengan $A N O V A$ dan uji korelasi Spearman. Kemaknaan ditentukan berdasarkan nilai p $<0,05$.

Hasil. Kadar seng serum rendah pada 53 (65\%) anak. Rerata kadar seng serum pada demam dengue (DD), demam berdarah dengue (DBD) dan SSD adalah 68,2 $\mu \mathrm{g} / \mathrm{dL}$ (SB 15,3), 64,8 $\mu \mathrm{g} / \mathrm{dL}(\mathrm{SB} 15,6)$ dan 59,2 $\mu \mathrm{g} / \mathrm{dL}$ (SB 15,0) ( $\mathrm{p}=0,09)$, sedangkan kadar feritin tinggi pada 79 (98\%) anak dengan rerata 1158,9 ng/ $\mathrm{mL}$ (SB 1766,8), 3048,2 ng/mL (SB 2566,2), $6891 \mathrm{ng} / \mathrm{mL}$ (SB 9822) (p<0,001). Terdapat hubungan kuat dan bermakna antara derajat berat penyakit dengan kadar feritin $(p<0,001 ; r=0,635)$, tetapi tidak terdapat hubungan dengan kadar seng serum ( $\mathrm{p}=0,043 ; \mathrm{r}=-0,225)$.

Kesimpulan. Spektrum klinis infeksi dengue berhubungan kuat dengan kadar feritin yang tinggi dan memiliki hubungan dengan kadar seng serum rendah. Sari Pediatri 2013;15(4):213-9.
\end{abstract}

Kata kunci: seng serum, feritin, infeksi dengue

\footnotetext{
Alamat korespondensi:

Prof. Dr. Alex Chairulfatah, Sp.A(K).Departemen Ilmu Kesehatan Anak Fakultas Kedokteran Universitas Padjadjaran Rumah Sakit Dr. Hasan Sadikin Jl. Pasteur No. 38 Bandung 40163, Indonesia. Telp. (022) 2035957,E-mail: Dianpus@bdg.centrin.net.id
}

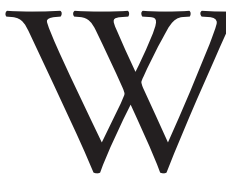

orld Health Organization tahun 2009 melaporkan bahwa penyakit infeksi dengue sampai saat ini masih merupakan masalah kesehatan yang sangat serius di daerah tropis, terutama di kawasan Asia Tenggara termasuk Indonesia, Asia Selatan, Amerika Tengah, dan Amerika Selatan. ${ }^{1}$ Demam 
berdarah dengue terdiri dari tiga fase, yaitu demam, toksik, dan konvalesens. Fase demam berlangsung 2-7 hari diikuti penurunan suhu tiba-tiba menjadi normal atau subnormal. Fase toksik berlangsung 24-48 jam merupakan periode kritis. Segera setelah penurunan suhu yang cepat dapat terjadi kekacauan sirkulasi dalam berbagai derajat akibat kebocoran plasma, dapat juga terjadi perbaikan klinis yang cepat apabila tidak disertai komplikasi. ${ }^{2,3}$ Manifestasi berat infeksi dengue yang dapat mengancam kehidupan dapat berupa syok akibat kebocoran plasma, perdarahan hebat, dan gangguan berat fungsi organ seperti hati, susunan saraf, ginjal, atau disfungsi miokardium. ${ }^{3,4}$ Kebocoran vaskular dapat menyebabkan seseorang mengalami syok hipovolemik, yang disebut sebagai sindrom syok dengue (SSD) atau dengue shock syndrome (DSS). ${ }^{5}$ Kematian akibat infeksi dengue berhubungan dengan DBD atau SSD, ${ }^{6}$ dengan syok lama, perdarahan masif, gagal napas atau ensefalopati dengue. ${ }^{7}$ Penyakit yang berat dapat berhasil ditatalaksana dengan pemantauan yang baik terhadap tanda bahaya dan terapi inisiasi dini berupa pemberian cairan intravena yang agresif, tetapi selama fase awal demam, sulit bagi klinisi untuk menentukan pasien mana yang akan menjadi berat. ${ }^{6}$

Sampai saat ini, bagaimana mekanisme dan apa molekul efektor yang memerantarai fenomena klinis yang nampak selama infeksi dengue klasik baik ringan, berat, maupun yang menyimpang masih belum diketahui. Penelitian masih dikembangkan pada hal tersebut agar memungkinkan deteksi secara dini infeksi dengue yang berat dan terapi spesifik untuk mencegah timbulnya penyakit yang berat serta kemungkinan pengembangan terapi yang lebih sederhana, murah dan mudah. ${ }^{8}$

Seng berperan dalam terjadinya kebocoran vaskular pada infeksi dengue yang berat melalui matriks metalloproteinase-9 (MMP-9) dan MMP2 , yaitu suatu enzim yang tergantung pada seng. ${ }^{5}$ Infeksi dengue pada sel dendritik dan sel endotel makrovaskular merangsang kebocoran vaskular melalui produksi berlebihan MMP-9 dan MMP-2 yang berakibat terjadinya perubahan permeabilitas endotel. ${ }^{59}$ Penelitian mengenai kadar seng serum pada infeksi dengue yang pernah dilakukan masih belum dapat menjelaskan hubungan kadar seng serum dengan derajat keparahan penyakit. ${ }^{10,11}$

Infeksi dan inflamasi akut menginduksi hambatan pelepasan besi yang terkumpul di dalam sel dan disimpan dalam bentuk feritin sehingga kadar besi serum menurun, hal tersebut menunjukkan tingkat virulensi dari mikroorganisme. Peningkatan feritin serum sebagai reaktan fase akut merefleksikan respons klinis untuk menghambat penggunaan besi serum oleh mikroorganisme. Kadar feritin serum pada infeksi dengue diyakini dapat menjadi prediktor terjadinya DBD. ${ }^{2}$

\section{Metode}

Penelitian observasional analitik rancangan potong lintang dengan data yang diambil secara konsekutif. Subjek penelitian adalah anak yang didiagnosis DD, $\mathrm{DBD}$, dan SSD yang menjalani perawatan rawat inap di ruang rawat anak RSUP. Dr. Hasan Sadikin, RSUD Kota Bandung, dan RSUD Cibabat, periode Januari 2012 sampai Mei 2012. Kriteria inklusi adalah 1) pasien infeksi dengue usia 1 bulan - 14 tahun, 2) memenuhi kriteria diagnosis klinis DD, DBD dan SSD menurut kriteria WHO tahun 1997 dan terbukti secara serologis dengan uji IgG dan atau IgM Immunoassay Dot-blot. Kriteria eksklusi adalah 1) terdapat penyakit infeksi lain selain infeksi dengue selama dirawat di rumah sakit, 2) menderita kelainan hematologi (anemia aplastik atau keganasan hematologi), 3) Sedang mendapatkan terapi imunosupresi (kortikosteroid dan atau kemoterapi), serta suplementasi seng lebih dari $10 \mathrm{mg}$ dalam 2 minggu terakhir sebelum dirawat. Penelitian ini telah mendapat persetujuan Komite Etik Penelitian Kesehatan Fakultas Kedokteran Universitas Padjadjaran/RS Dr. Hasan Sadikin Bandung. Persetujuan ikut serta dalam penelitian didapatkan dari orangtua/wali pasien.

Data anamnesis, pemeriksaan fisis, laboratorium, dan pemeriksaan kadar seng dan feritin serum dicatat dalam formulir khusus. Pemeriksaan seng serum menggunakan metode atomic absorption spectroscopy (AAS) di laboratorium Seameo Fakultas Kedokteran Universitas Indonesia, Jakarta, sedangkan kadar feritin serum menggunakan metode electrochemiluminescense immunoasssay (ECLIA) dari Roche di laboratorium Prodia Bandung. Pemeriksaan serologis IgM dan IgG antidengue dengan metode rapid test dilakukan pada hari sakit keenam menggunakan kit Core IgG/IgM Strip dengan prinsip kerja immunochromatography.

Analisis data dilakukan dengan menggunakan program SPSS for windows versi 17.0 pada derajat 
kepercayaan $95 \%$ dengan nilai $\mathrm{p} \leq 0,05$.

\section{Hasil}

Delapan puluh satu anak terdiri dari 42 (52\%) anak perempuan dan 39 (48\%) anak laki-laki, dengan rentang usia antara 2-13 tahun memenuhi kriteria inklusi. Spektrum klinis infeksi dengue berturut-turut didapatkan jumlah subyek DD 33 (40\%), DBD $24(30 \%)$ dan SSD $24(30 \%)$ anak. Berdasarkan spektrum klinis didapatkan perbedaan antara laki-laki dan perempuan $(\mathrm{p}=0,014)$. Karakteristik subyek penelitian tertera pada Tabel 1. Berdasarkan respon imunologis sebagian besar 79 (97\%) subyek memberikan respons imun sekunder, sedangkan respons imun primer pada $2(3 \%)$ subyek. Kedua subyek dengan respon imun primer didiagnosis DD, masing-masing berusia 5 dan 10 tahun.

Duapuluh dua (27\%) subyek datang dalam keadaan syok, 2 di antaranya meninggal dalam waktu kurang dari 24 jam perawatan di rumah sakit. Satu (2\%) subyek yang awalnya didiagnosis DBD menjadi SSD dan satu subyek yang awalnya didiagnosis DD

Tabel 1. Karakteristik subjek penelitian

\begin{tabular}{lccc}
\hline & \multicolumn{3}{c}{ Spektrum klinis $\mathrm{n}(\%)$} \\
\cline { 2 - 4 } Karakteristik & $\mathrm{DD}$ & $\mathrm{DBD}$ & $\mathrm{SSD}$ \\
\cline { 2 - 4 } & $(\mathrm{n}=33)$ & $(\mathrm{n}=24)$ & $(\mathrm{n}=24)$ \\
\hline Jenis kelamin & & & \\
$\quad$ Laki-laki & $17(51,5)$ & $6(25)$ & $16(67)$ \\
$\quad$ Perempuan & $16(48,5)$ & $18(75)$ & $8(33)$ \\
Usia (tahun) & & & $2(8)$ \\
$<5$ & $3(9)$ & $4(17)$ & $19(80)$ \\
$5-12$ & $27(82)$ & $19(79)$ & $3(12)$ \\
$>12$ & $3(9)$ & $1(4)$ & \\
Status gizi & & $2(8)$ & $13(4)$ \\
Lebih & $0(0)$ & $19(79)$ & $10(42)$ \\
Baik & $21(63)$ & $3(13)$ & \\
Kurang & $12(37)$ & & \\
\hline
\end{tabular}

Tabel 2. Perbedaan kadar seng dan feritin serum

\begin{tabular}{lcccc}
\hline \multirow{2}{*}{ Kadar seng dan feritin } & \multicolumn{3}{c}{ Spektrum klinis } \\
\cline { 2 - 4 } Kadar seng serum & DD & DBD & SSD \\
Rerata (SB) & $68,2(15,3)$ & $64,8(15,6)$ & $59,2(15,0)$ & $\mathrm{p}=0,09^{*}$ \\
Median & 66,9 & 62,8 & 54,9 & \\
Rentang & $44,5-115,8$ & $38,9-92,9$ & $30,6-91,8$ & \\
Normal & $14(42)$ & $9(37)$ & $5(21)$ & \\
Rendah & $19(58)$ & $15(63)$ & $19(79)$ & \\
Kadar feritin serum & & & \\
Rerata (SB) & $1158,9(1766,8)$ & $3048,2(2566,2)$ & $6891(9822)$ & $\mathrm{p}<0,001^{*}$ \\
Median & 557,8 & 1673,5 & 3062 & \\
Rentang & $104,2-9565$ & $533,4-8464$ & $1061,0-47,525$ & \\
Normal & $2(7)$ & $0(0)$ & $0(0)$ & \\
Tinggi & $31(93)$ & $24(100)$ & $24(100)$ & \\
\hline
\end{tabular}

Keterangan: ") Uji ANOVA 
menjadi SSD dalam perawatan di rumah sakit. Duabelas (29\%) subyek yang awalnya didiagnosis DD berubah menjadi DBD. Mayoritas subyek 58 $(72 \%)$ datang berobat ke rumah sakit pada hari sakit keempat dan kelima, dari jumlah tersebut 17 (21\%) di antaranya datang ke rumah sakit dalam keadaan syok. Lima subyek (21\%) dari 24 pasien SSD datang ke rumah sakit pada hari sakit kurang dari 4 hari.

Tabel 2 menunjukkan kadar seng yang rendah pada mayoritas (65\%) subyek dengan nilai rerata di bawah normal pada ketiga spektrum klinis. Uji $A N O V A$ menunjukkan tidak terdapat perbedaan kadar seng serum pada ketiga spektrum klinis infeksi dengue $(\mathrm{p}=0,09)$, tetapi terdapat kecenderungan untuk rendah sesuai derajat keparahan penyakit. Kadar feritin serum yang tinggi ditemukan pada 79 (98\%) subyek. Hasil uji ANOVA menunjukkan terdapat perbedaan kadar feritin serum yang sangat bermakna $(p<0,001)$ antara ketiga spektrum klinis infeksi dengue.

Uji Spearman dilakukan untuk mengetahui korelasi antara spektrum klinis infeksi dengue dengan kadar seng dan feritin serum (Tabel 3). Hasil analisis menunjukkan terdapat hubungan yang bermakna antara spektrum klinis infeksi dengue dengan kadar seng serum yang rendah $(\mathrm{p}=0,043)$, tetapi memiliki kekuatan hubungan yang lemah $(\mathrm{r}=-0,225)$. Hubungan antara spektrum klinis infeksi dengue dengan kadar feritin serum yang tinggi didapatkan bermakna $(\mathrm{p}<0,001)$ dan memiliki hubungan yang kuat $(r=0,635)$. Artinya semakin berat spektrum klinis infeksi dengue semakin rendah kadar seng dan makin tinggi kadar feritin serum. demam, sulit bagi klinisi untuk menentukan pasien mana yang akan menjadi berat. ${ }^{6}$ Kesulitan tersebut merupakan suatu masalah, mengingat keterbatasan tenaga dan fasilitas untuk memantau pasien secara ketat, terutama di rumah sakit daerah. Sangat mungkin pasien dengan infeksi dengue yang berat sudah pernah datang ke dokter atau fasilitas kesehatan pada fase awal demam. Oleh karena itu, diperlukan indikator dini atau prediktor terjadinya infeksi dengue yang berat pada fase awal demam yang murah dan mudah sebelum terjadi kebocoran vaskular.

Usia terbanyak terdapat pada rentang usia 5-12 tahun. Beberapa penelitian yang telah dilakukan sebelumnya menunjukkan insiden infeksi dengue pada anak lebih sering terjadi pada anak kelompok usia 5-9 tahun. ${ }^{12,13}$ Tidak adanya subyek berusia kurang dari 2 tahun pada penelitian kami mungkin disebabkan adanya pergeseran kelompok usia pada kejadian infeksi dengue. Beberapa penelitian juga melaporkan adanya peningkatan kasus DBD pada usia remaja dan dewasa muda. ${ }^{12,14}$ Perbedaan berdasarkan jenis kelamin mungkin karena pengambilan sampel dilakukan dengan cara konsekutif. Banyaknya pasien DD yang menunjukkan respon imun sekunder mengindikasikan bahwa tidak semua infeksi sekunder akan menjadi berat. Sindrom syok dengue pada umumnya terjadi pada hari sakit ke-3 sampai hari ke-5.,15 Dijumpai 5 subyek dari seluruh pasien SSD datang ke rumah sakit pada hari sakit $\leq 3$ hari mengindikasikan bahwa syok dapat terjadi pada demam $\leq 3$ hari sehingga kewaspadaan klinis perlu dipertajam.

Tabel 3 Korelasi antara spektrum klinis infeksi dengue dengan kadar seng dan feritin serum

\begin{tabular}{lcc}
\hline Hubungan* & Koefisien hubungan $(\mathrm{r})$ & Nilai p \\
\hline Spektrum klinis dengan seng serum & $-0,225$ & 0,043 \\
Spektrum klinis dengan feritin serum & 0,635 & $<0,001$ \\
\hline
\end{tabular}

Keterangan: *) berdasarkan uji korelasi Spearman

\section{Pembahasan}

Duabelas (29\%) subyek yang didiagnosis awal sebagai DD dalam perawatan di rumah sakit menjadi DBD dan $1(2 \%)$ subyek menjadi SSD. Demikian juga satu subyek yang didiagnosis awal DBD menjadi SSD. Hal tersebut menunjukkan bahwa selama fase awal
Hubungan antara derajat beratnya penyakit infeksi dengue dengan status gizi masih merupakan kontroversi. Beberapa penelitian menunjukkan bahwa status gizi tidak berhubungan dengan beratnya penyakit, ${ }^{16,17}$ sedangkan penelitian lain menyimpulkan bahwa status gizi lebih merupakan faktor risiko untuk mengalami infeksi dengue berat. ${ }^{18}$ 
Vindy Ruslianti dkk: Hubungan spektrum klinis infeksi dengue dengan kadar seng dan feritin serum

Kami menemukan status gizi baik, kurang, dan lebih. Semua subyek dengan gizi lebih mengalami DBD atau SSD. Beberapa penelitian mendapatkan bahwa status gizi tidak berhubungan dengan prevalensi dengue yang berat, sedangkan penelitian lain menyimpulkan bahwa hanya subyek dengan status gizi lebih yang berisiko akan mengalami infeksi dengue yang berat.

Kadar seng serum rendah pada 65\% subyek meski hanya $31 \%$ berstatus gizi kurang. Kadar seng serum pada ketiga spektrum klinis infeksi dengue menunjukkan tidak terdapat perbedaan, tetapi terdapat kecenderungan rendah sesuai derajat keparahan penyakit. Uji korelasi menunjukkan terdapat korelasi dengan kekuatan hubungan lemah antara spektrum klinis infeksi dengue dengan kadar seng serum. Artinya semakin berat infeksi dengue maka semakin rendah kadar seng serum. Seng berperan pada infeksi dengue yang berat sehubungan dengan peningkatan produksi MMP-2 dan MMP-9, yaitu suatu enzim yang tergantung seng yang berperan dalam terjadinya kebocoran plasma pada infeksi dengue. Peningkatan MMP-2 dan MMP-9 pada infeksi dengue mengakibatkan permeabilitas endotel meningkat sehingga terjadi kebocoran plasma. ${ }^{5}$ Seng berfungsi sebagai katalisator dan berikatan dengan MMP melalui zinc binding-site. ${ }^{19}$ Kadar seng yang rendah mungkin berkaitan dengan penggunaan seng yang meningkat untuk aktivitas MMP tersebut, tetapi hal tersebut masih perlu dibuktikan dengan penelitian yang mengukur kadar seng dan MMP secara bersamaan pada infeksi dengue.

Rendahnya kadar seng juga diketahui dapat meningkatkan penanda stres oksidatif dan sitokin inflamasi. ${ }^{20}$ Keadaan tersebut mungkin saja memperberat infeksi dengue yang terjadi karena kebocoran plasma juga diyakini karena tingginya mediator inflamasi terlarut seperti TNF- $\alpha$, IL-6, IL-1 $\beta$, IL-8 IFN $\gamma$ dan IL-2.5 Sembilan dari 12 subyek yang awalnya didiagnosis sebagai DD menjadi DBD dalam perawatan di rumah sakit dan 1 subyek menjadi SSD serta satu subyek yang awalnya didiagnosis DBD menjadi SSD, memiliki kadar seng yang rendah.

Dua peneliti sebelumnya menduga bahwa kadar seng yang rendah pada infeksi dengue merupakan faktor risiko terjadinya infeksi dengue yang berat. ${ }^{10,11}$ Dugaan berdasarkan masih tingginya kejadian infeksi dengue di Indonesia dengan CFR yang masih cukup tinggi, ${ }^{21,22}$ serta lebih dari $30 \%$ balita di Asia tenggara dan beberapa wilayah Indonesia mengalami defisiensi seng. ${ }^{23,24}$ Defisiensi seng dapat mengganggu berbagai aspek dari fungsi imun serta dapat meningkatkan kerentanan terhadap infeksi. ${ }^{23,25,26}$ Kelemahan penelitian kami adalah tidak diketahuinya kadar seng serum subyek sebelum sakit sehingga kadar seng serum yang rendah masih mungkin sudah terjadi sebelum anak menderita infeksi dengue. Hal tersebut menimbulkan pertanyaan apakah kadar seng yang rendah sebelum sakit atau besarnya penurunan kadar seng selama sakit yang berperan dalam beratnya derajat penyakit. Penelitian yang memantau kadar seng selama perjalanan penyakit diharapkan dapat menjelaskan pemikiran tersebut.

Kadar feritin ditemukan tinggi pada 79 (98\%) subyek. Kadar feritin berbeda antara ketiga spektrum klinis infeksi dengue dan memiliki hubungan yang kuat dengan derajat beratnya penyakit. Hasil penelitian kami mendukung penelitian sebelumnya mengenai kadar feritin serum pada infeksi dengue yang mendapatkan bahwa kadar feritin serum sebagai reaktan fase akut dapat dijadikan prediktor terjadinya DBD. ${ }^{2}$

Inflamasi dan stres oksidatif memiliki peran penting pada regulasi feritin. Peningkatan sitokin inflamasi terutama TNF- $\alpha$ dan IL-2 seperti yang terjadi pada berbagai jenis infeksi, ${ }^{2,27}$ termasuk infeksi dengue, , ${ }^{428-30}$ meningkatkan sintesis feritin oleh sel mesenkim, hepatosit, dan monosit makrofag. Peningkatan sintesis feritin ditunjukkan untuk mengurangi ketersediaan besi dalam sel sehingga mencegah penggunaan besi untuk metabolisme mikroorganisme. ${ }^{2,27}$

\section{Kesimpulan}

Spektrum klinis infeksi dengue menunjukkan hubungan yang kuat dengan kadar feritin serum. Perlu dipertimbangkan pemeriksaan kadar feritin serum sebagai indikator dini infeksi dengue yang berat pada fase awal demam pada anak yang dicurigai mengalami infeksi dengue.

\section{Daftar pustaka}

1. World Health Organization. Dengue: Guidelines for diagnosis, treatment, prevention and control. New 
Vindy Ruslianti dkk: Hubungan spektrum klinis infeksi dengue dengan kadar seng dan feritin serum

edition. Geneva; WHO: 2009

2. Chaiyaratana W, Chuansumrit A, Atamasirikul K, Tangnararatchkit K. Serum feritin levels in children with dengue infection. Southeast Asian J Trop Med Public Health 2008;39:832-6.

3. Ranjit S, Kissoon N. Dengue hemorrhagic fever and shock syndromes. Pediatr Crit Care Med 2011;12:90 -100 .

4. Dharma R, Hadinegoro SR, Priatni I. Disfungsi endotel pada demam berdarah dengue. Makara Kesehatan 2006;10:17-23.

5. Luplertlop N, Misse D. MMP cellular responses to dengue virus infection-induced vascular leakage. Jpn J Infect Dis 2008;61:293-301.

6. Guzman MG, Halstead SB, Artsob H, Buchy P, Farrar J, Gubler DJ, dkk. Dengue: a continuing global threat. Nature Rev Microbiol 2010:S7-16.

7. World Health Organization. Dengue Hemorrhagic Fever: Diagnosis, Treatment, Prevention and Control. Edisi kedua. Geneva: World Health Organization, 1997.

8. Halstead SB. Global perspective on dengue research. Dengue Bull 2000;24:77-9.

9. Luplerdlop N, Misse D, Bray D, Deleuze V, Gonzalez JP, Leardkamolkarn V, Yssel H, dkk. Dengue-virusinfected dendritic cells trigger vascular leakage through metalloproteinase overproduction. EMBO reports 2006;7:1176-81.

10. Widagdo. Blood zinc levels and clinical severity of dengue hemorrhagic fever in children. Southeast Asian J Trop Med Pub Health 2008;39:610-6.

11. Yuliana N, Fadil R, Chairulfatah A. serum zinc levels and clinical severity of dengue infection in children. Paediatr Indones 2009;49;6-10.

12. Narayan M, Arafind MA, Thilothammal N, Prema R, Sargunam CSR, Ramamurty N. Dengue fever epidemic in Chennai-A study of clinical profile and outcome. Indian Pediatr 2002;39:1027-33.

13. Junia J, Garna H, Setiabudi D. Clinical risk factors for dengue shock syndrome in children. Paediatr Indones 2007;47:7-11.

14. Hammond SN, Balmaseda A, Perez L, tellez Y, Saborio SI. Differences in dengue severity in infants, children and adults in a 3-years hospital-base study in Nicaragua. Am J Trop Med Hgy 2006;73:1063-70.

15. World Health Organization. Dengue and dengue haemorrhagic fever. Fact Sheet, WHO no. 17. Geneva; 2002 (Diunduh 9 September 2008). Tersedia dari: http://www.who.int/mediacentrelfactsheets/fl 17/en/print. html.

16. Tantracheewathorn T, Tantracheewathorn S. Risk Factors of dengue shock syndrome in children. J Med Assoc Thai 2007;90:272-7.

17. Hung NT, lan NT, Lei HY, Lin YS, Lien LB. Association between sex, nutritional status, severity of dengue hemorhagic fever, and immune status in infants with dengue hemorhagic fever. Am J Trop Med Hyg 2005;72:370-4.

18. Pichainarong N, Mongkalangoon N, Kalayanarooj S, Chaveepojnkarnjorn W. Relationship between body size and severity of dengue hemorrhagic fever among children aged 0-14 years. Southeast Asian J trop Med Pub Health 2006;37:283-9.

19. Isaksen B, Fagerhol MK. Calprotectin inhibits matrix metalloproteinases by sequestration of zinc. J Clin Pathol: Mol Pathol 2001;54:289-92.

20. Prasad A. Clinical, immunological, anti-inflammatory and antioxidant roles of zinc. Exp Geront 2008; 43:370-377.

21. Departemen Kesehatan RI. Profil kesehatan Indonesia 2007. Jakarta: Departemen Kesehatan RI;2008.

22. Departemen Kesehatan RI. Profil kesehatan Indonesia 2008. Jakarta: Departemen Kesehatan RI;2009.

23. Caulfield LE, Black RE. Zinc deficiency. Dalam: Ezzati M, Lopez AD, Rodgers A, Murray CJL, penyunting. Comparative Quantification of Health Risks: Global and regional burden of disease, attributable to selected major risk factor. Geneva: World Health Organization;2004.

24. Herman S. Studi masalah gizi mikro di Indonesia. [Diunduh 26 Oktober 2010]; Tersedia dari: http://www. p3gizi.litbang.depkes.go.idlindex.php.

25. Black RE. Zinc deficiency, infectious disease and mortality in the developing world. J Nutr 2003;133(5 Suppl 1):1485S-9S.

26. Fischer Walker C, Black RE. Zinc and the risk for infectious disease. Annu Rev Nutr 2004;24:255-75.

27. Recalcati S, Invernizzi P, Arosio P, Cairo G. New functions for an iron storage protein: The role of ferritin in immunity and autoimmunity. J Auto-imunn 2008;30:84-9.

28. Guha-Sapir D, Schimmer B. Dengue fever: new paradigms for a changing epidemiology. Emerg Themes Epidemiol 2005;2:1-10.

29. Clyde K, Kyle J, Harris E. Recent advances in deciphering viral and host determinants of dengue virus replication and pathogenesis. J Virol 2006;80:11418-31.

30. Juffrie M, Meer G, Hack C, Haasnoot K, Sutaryo, 
Vindy Ruslianti dkk: Hubungan spektrum klinis infeksi dengue dengan kadar seng dan feritin serum

Veerman A, dkk. Inflammatory mediators in dengue virus infection in children: Interleukin- 8 and its relationship to neutrophil degranulation. Infect Immun 2000;68:702-7. 